\title{
Non-Medical Factors Associated with the Outcome of Treatment of Chronic Non-Malignant Pain: A Cross-Sectional Study
}

\author{
Irena Kovačević ${ }^{1,2, *}$, Višnja Majerić Kogler ${ }^{3}$, Valentina Krikšić ${ }^{1,4}$, Boris Ilić ${ }^{1}\left(\right.$, Adriano Friganović ${ }^{1,5}{ }^{\circledR}$, \\ Štefanija Ozimec Vulinec ${ }^{1}$, Jadranka Pavić ${ }^{1}$, Milan Miloševićc ${ }^{6} @$, Petra Kovačević ${ }^{7}(1)$ and Davorina Petek ${ }^{2}$
}

Citation: Kovačević, I.; Majerić Kogler, V.; Krikšić, V.; Ilić, B.;

Friganović, A.; Ozimec Vulinec, Š.;

Pavić, J.; Milošević, M.; Kovačević, P.; Petek, D. Non-Medical Factors Associated with the Outcome of Treatment of Chronic Non-Malignant Pain: A Cross-Sectional Study. Int. J. Environ. Res. Public Health 2022, 19, 2881. https://doi.org/10.3390/ ijerph19052881

Academic Editor: Paul B. Tchounwou

Received: 1 February 2022

Accepted: 28 February 2022

Published: 1 March 2022

Publisher's Note: MDPI stays neutral with regard to jurisdictional claims in published maps and institutional affiliations.

Copyright: (C) 2022 by the authors. Licensee MDPI, Basel, Switzerland. This article is an open access article distributed under the terms and conditions of the Creative Commons Attribution (CC BY) license (https:// creativecommons.org/licenses/by/ $4.0 /)$.
1 Department of Nursing, University of Applied Health Sciences, Mlinarska 38, 10000 Zagreb, Croatia; valentina@domnius.hr (V.K.); boris.ilic@zvu.hr (B.I.); adriano@hdmsarist.hr (A.F.); stefanija.ozimec-vulinec@zvu.hr (Š.O.V.); jadranka.pavic@zvu.hr (J.P.)

2 Department of Family Medicine, Faculty of Medicine, University of Ljubljana, Poljanski nasip 58, 1000 Ljubljana, Slovenia; davorina.petek@gmail.com

3 School of Medicine, University of Zagreb, Šalata 3, 10000 Zagreb, Croatia; vkogler1944@gmail.com

4 Institution for Home Healthcare Domnius, 10000 Zagreb, Croatia

5 Department of Anaesthesiology and Intensive Medicine, University Hospital Centre Zagreb, Kišpaticeva 12, 10000 Zagreb, Croatia

6 Andrija Štampar School of Public Health, University of Zagreb School of Medicine, 10000 Zagreb, Croatia; milan.milosevic@snz.hr

7 Department of Rheumatology, Physical and Rehabilitation Medicine, University Hospital Centre "Sestre Milosrdnice", 10000 Zagreb, Croatia; petrakova13@gmail.com

* Correspondence: irena.kovacevic1@gmail.com

\begin{abstract}
Background: Chronic pain is a global public health issue with increasing prevalence. Chronic pain causes sleep disorder, reactive anxiety, and depression, impairs the quality of life; it burdens the individual and society as a whole. The aim of this study was to examine non-medical factors related to the outcome of the treatment of chronic non-malignant pain. Methods: A crosssectional study with two groups of patients was conducted using a questionnaire with biological, psychological, and social characteristics of patients. Since this study was cross-sectional, it was not possible to determine whether some factors were the cause or the consequence of unsuccessful treatment outcome, which is at the same time one of the disadvantages of cross-sectional studies. Results: The poor outcome of the treatment of chronic non-malignant pain in a multivariate binary logistic regression model was statistically significantly associated with the lower quality of life $(\mathrm{OR}=0.95$ (95\% CI: 0.91-0.99; $p=0.009)$, and higher depression level OR $=1.08$ (95\% CI: $1.02-1.14$; $p=0.009$ ). The outcome of the treatment was not directly related to social support measured by the multivariate binary logistic regression model (OR $=1.04,95 \% \mathrm{CI}: 0.95-1.15, p=0.395)$, but solitary life (without partner) was (OR $=2.16$ (95\% CI: $1.03-4.53 ; p=0.043)$. Conclusion: The typical patient with a poor pain management outcome is retired, presents depressive behavior; their pain disturbs general activity and sleeping. Moreover, they have a physically disturbed quality of life and require self-treatment due to the inaccessibility of doctors and therapies. The principle of treatment of patients with chronic, non-malignant pain should take into account a biopsychosocial approach with individually adjusted procedures.
\end{abstract}

Keywords: chronic non-malignant pain; quality of life; depression; social support; self-treatment

\section{Introduction}

Chronic non-malignant pain (CNMP) has been recognized as a great public health problem that imposes significant economic and social burdens [1]; it has a prevalence prevalence in the population of around 20-50\% [2]. European data indicate that moderateand high-intensity chronic pain, with serious impacts on daily living, social status and working life, occurs in 19\% of the European adult population [1]. 
Chronic non-malignant (CNMP) pain is defined with respect to its duration and recurrence. There are several definitions of CNMP [3-5]; one suggests that it is pain whose duration is longer than the time of expected withdrawal of the injury or completion of the surgery and lasts more than three months [3]. Chronic non-malignant pain (CNMP) reduces physical activity and may even cause disability which in turn affects other aspects of the patient's everyday life [6].

Of many factors associated with chronic CNMP (depression, anxiety, excessive chronic pain awareness, coping strategies and pain belief), depression has been identified as the key factor. The higher intensity of pain is associated with depressive outcomes [7] and depression significantly affects effective pain treatment and influences the reduction in quality of life [7-10]. The musculoskeletal pain is one of the most common chronic, nonmalignant conditions, and is strongly associated with depression [11]. Individuals who suffer from musculoskeletal pain, and in addition suffer with depression, are on sick leave for two times longer than those in pain but not depressed [12,13].

The results of the previous studies also indicate the association of chronic pain with various demographic characteristics. Some of the socio-demographic factors associated with chronic pain are female gender, old age, lower socioeconomic status, geographic and cultural background, employment status, and abuse and negative human relations in medical history [14]. Some studies reported the association of obesity with chronic pain in elderly men and women; consequently, moderate obesity was associated with a twofold higher probability for chronic pain occurrence in comparison to those of a normal body weight [15]. According to Shawe al. and Hestbaeket et al., there is also association of some factors with the site of pain, so that certain social factors, such as the income, accessibility to the health care [16] and lower educational level [17] may be related to the chronic back pain [18].

The pain includes all aspects of the patient's nature, from the physiology and biochemistry, over-emotional and motivational appearance to psychological processes, social relationships and mental consciousness [19]. It was demonstrated that social support has an effect on chronic pain intensity, and various sources of support can encourage the person to use the facing strategy [20]. A literature review showed insufficient data in this field, especially in Croatian settings [21]. The aim of this study was to examine non-medical factors related to the outcome of the treatment of chronic non-malignant pain.

The objectives we wanted to achieve were to:

1. Identify the differences in the quality of life, patient satisfaction, and self-rated health, in the group of participants with successful chronic non-malignant pain management, and in the group where the intensity of pain was not reduced despite treatment;

2. Determine the differences in the biological, psychological, and social factors between the two groups;

3. Establish the association of selected non-medical factors with the treatment outcome of chronic non-malignant pain.

\section{Methods}

\subsection{Type of Research}

A cross-sectional study with two groups of patients was carried out at the University Clinical Hospital Center "Sestre milosrdnice" in Zagreb (Croatia). The data were collected in a period of approximately1 and a half years (18 April 2018-15 November 2019).

\subsection{Participants}

The consecutive patients were visitors of the Department of Anesthesiology, Reanimatology, Intensive Medicine and Pain Management at the University Clinical Centre "Sestre milosrdnice" in Zagreb, aged 18 or older, with chronic, non-malignant pain. The patients gave informed consent for participation in the research. The study was approved by the Ethics Committee of the University Hospital Center (UHC) "Sestre milosrdnice" in Zagreb, Croatia, at its regular session held on 25 May 2016, file \# EP-7811/16-6. The 
Ethical Committee of the University Hospital Center (UHC) "Sestre milosrdnice" operates in line with the principles of the International Conference on Harmonisation (ICH GCP) and the Helsinki Declaration. After a thorough written and oral explanation of the ethical principles, purpose, and course of research, they were asked to give informed consent. The first group of participants (156) were patients who had successful treatment of pain but were still visiting the pain clinic once per month, for following 4-5 months for a regular follow-up. The second group consisted of participants (180) who had been treated for pain in the Clinic for a longer period (more than a year) but did not experience significant pain relief. Every included patient from both groups answered a specially developed questionnaire. The nurse additionally checked whether the patients properly completed the questionnaire understood questions and signed informed consent to participate in the study. In this way, the number of non-answered questions was reduced, and the credibility of answers was increased.

\subsection{Instrument}

The research instrument was a survey of the factors that are associated with the treatment outcome of chronic non-malignant pain and additional questions about selftreatment based on the previously made qualitative study [22].

In this study, several internationally validated questionnaires/scales were used. All of them, except for the Patient Satisfaction Questionnaire Short Form (PSQ-18) [23,24], have already been validated in Croatia. For the PSQ-18, a 2-way translation and validation was performed.

The following questionnaires have been used:

Patient Satisfaction Questionnaire Short Form. Seven dimensions of patient satisfaction with physicians were assessed, including general satisfaction, technical quality, human relations, communication, financial aspects, time spent with the physician, and availability and convenience $[23,24]$.

Functional Comorbidity Index (FCI) used to adjust for the effect of comorbidity on physical function. The FCI was specifically developed for use in a general population with physical function, not mortality, as the outcome of interest. The FCI as created by Groll et al. is an 18-item list of comorbid conditions without weighting (range 0-18) [25].

CES-D as a screening test for depression and depressive disorder. The 20-item scale remains 1 of the most widely used instruments in the field of psychiatric epidemiology. The score is the sum of the 20 questions. The possible range is $0-60$. If more than 4 questions are miss answers, the CES-D questionnaire should not be scored. A score of 16 points or more is considered depressed [26].

Generalized Anxiety Disorder 7 (GAD-7) to measure the level of anxiety. In this form of self-assessment, subjects are asked to rate their anxiety-related problems on the 4-point scale $(0=$ not at all; $3=$ almost every day). A total sum of points ranges from 0 to 21 , where the higher score is associated with more serious anxiety. Regarding the severity category in this study, we followed the recommendations from the original version: not at all/normal (0 to 5 points), mild anxiety (5 to 9 points), moderate anxiety (10 to 14 points), and severe anxiety (15 to 21 points) $[27,28]$.

Duke University Religion Index-DUREL as a measure for religiosity dimensions. This is a reliable measure of self-estimation of key religiosity dimensions. It comprises five items with responses rated on the Likert 1-5-point scale (1-does not apply to me at all; 5 -applies to me completely). The questionnaire measures extrinsic religiosity through estimation of the organized religiosity (OR) and the non-organized religiosity (NOR). The other part of the questionnaire measures intrinsic religiosity (IR) $[29,30]$.

Social support scale. This 8-item scale measures the extent of support in the form of "encouragement", "useful information", "direct assistance", i.e., "offered things necessary to the subjects" etc., provided by people close to the subjects. Responses are rated from 1 (indicating minimal support) to 4 (indicating maximum support). The response "never" 
brings 1 point, "sometimes" brings 2 points, "often" brings 3 points, and "always" brings 4 points [31].

The World Health Organization WHOQOL-BREF quality of life assessment WHOQOLBREF questionnaire. The version of the WHOQOL-100 questionnaire was created by the World Health Organization for the quality-of-life assessment [32-34]. The questionnaire contains 26 questions and each one is scored by the Likert scale from 1 (the worst) to 5 (the best) points. Following the transformation of points, which is conducted in 2 steps, the points for each domain are positioned on the 0-100 scale. From original results, a result for each domain of quality of life is calculated: physical health, psychic performance, social interaction, and environment, and additionally the overall satisfaction with quality of life and satisfaction with health are measured by two specific items which are considered separately. Results for each domain are calculated as a sum of results of each item. The points from each domain are transformed on the 0-100 scale in order to be compared with the original questionnaire and more legible presentation of results. A higher number of points means a higher quality of life in each of domains [33]. In this study, a validated Croatian version of the questionnaire was used [35].

These questionnaires were chosen in the present study because they were suitable for the aim of the study because they are internationally validated questionnaires already used and validated in Croatia in various studies.

We also tested several statements about self-treatment, based on previous qualitative work [22].

\subsection{Independent Explanatory Variables:}

1. Socio-demographic characteristics (age, gender, employment status, education level, marital status, financial status, place of residence);

2. Self-treatment of pain. The questions were drawn from a previously conducted qualitative study of self-treatment of chronic non-malignant pain [22];

3. Psychological factors: the degree of depression (measured by Center for Epidemiological Studies Depression Scale (CES-D) [26], and Anxiety (measured by Generalized Anxiety Disorder 7- item (GAD-7) scale) [27,28];

4. Social factors. The social support was measured by a scale constructed for the purpose of Šverko et al. [31], which is an adapted version of the Abbey, Abramis, and Caplan scale [36];

5. The outcome variable was the outcome of the treatment of chronic non-malignant pain. The outcome was dichotomous: the successful outcome (cured/improved) was defined as the control of pain achieved, with the pain intensity of 0-3 measured by NRS. The unsuccessful outcome (not cured) was defined as the pain intensity 4-10 on NRS even after one year of treatment or longer.

\subsection{Statistical Analysis}

The data were interpreted with a statistical significance level of at least $5 \%$. The Kolmogorov-Smirnov test was used to assess the distribution of quantitative data. According to the findings, appropriate non-parametric statistical tests were used in the following analyses. Categorical variables were presented as frequencies and corresponding percentages while quantitative variables through medians and interquartile ranges (25th to 75th percentile).

Differences in the categorical variables were analyzed with the chi-square test while Fisher exact test or Fisher-Freeman-Halton exact test was used where cells contained less than 10 participants. Mann-Whitney $U$ test was used to analyse differences between participants with successful chronic non-malignant pain management (NRS 0-3) and participants where the intensity of pain was not reduced despite treatment (NRS 4-10).

A binary logistic regression model was made to predict the poor outcome of the treatment of patients with chronic non-malignant pain with predictors that include the significant variables from previous univariate analyses. 
$p$ values below 0.05 were considered significant. Statistical software IBM SPSS Statistics, version 25.0 was used in all statistical procedures.

\section{Results}

\subsection{Descriptive Statistics}

Sample Parameters

A total of 180 participants were included in group 1 (participants where the intensity of pain was not reduced despite treatment (NRS 4-10), and 156 in group 2 (participants with successful chronic non-malignant pain management (NRS 0-3). Moreover, 24 patients were excluded from the analysis because they did not fully answer all the questions, i.e., they did not meet the set criteria.

Differences in categorical socio-demographic data between participants with successful chronic non-malignant pain management and participants where the intensity of pain was not reduced despite treatment (NRS 4-10) are shown in Table 1. There was a significant difference in educational level (NRS 0-3 group had greater number of higher educated participants, $p=0.003$ ), working status (significantly higher number of retired people in NRS 4-10 group; $p=0.002)$, marriage status $(p=0.039)$, financial status $(p=0.002)$ and salary $(p<0.001)$. Some of these differences can be ascribed to significantly older age of NRS 4-10 group: 62.5 (54.0-71.8) years vs. $57.0(46.3-66.0)$ years $(p<0.001$. (Table 2$)$ ).

Table 1. Differences in sociodemographic data between the two groups of participants according to the outcome of chronic pain treatment: $\left(\chi^{2}\right)$ test.

\begin{tabular}{|c|c|c|c|c|c|c|}
\hline \multirow{3}{*}{\multicolumn{2}{|c|}{ Socio-Demographic Data }} & \multicolumn{4}{|c|}{ Groups } & \multirow{3}{*}{$p$} \\
\hline & & \multicolumn{2}{|c|}{ NRS 4-10 } & \multicolumn{2}{|c|}{ NRS 0-3 } & \\
\hline & & $\mathbf{N}$ & $\%$ & $\mathbf{N}$ & $\%$ & \\
\hline \multirow{2}{*}{ Gender } & Male & 26 & $14.44 \%$ & 35 & $22.44 \%$ & \multirow[b]{2}{*}{0.058} \\
\hline & Female & 154 & $85.56 \%$ & 121 & $77.56 \%$ & \\
\hline \multirow{3}{*}{ Education } & Elementary school & 38 & $21.11 \%$ & 18 & $11.54 \%$ & \multirow{3}{*}{0.009} \\
\hline & University or college degree & 102 & $56.67 \%$ & 84 & $53.85 \%$ & \\
\hline & Master's or Ph.D. degree & 40 & $22.22 \%$ & 54 & $34.62 \%$ & \\
\hline \multirow{4}{*}{$\begin{array}{l}\text { Place of } \\
\text { living * }\end{array}$} & Village & 25 & $13.89 \%$ & 16 & $10.26 \%$ & \multirow{4}{*}{0.697} \\
\hline & Small town $(<5000$ inhabitans $)$ & 12 & $6.67 \%$ & 9 & $5.77 \%$ & \\
\hline & $\begin{array}{c}\text { Bigger town (5000-50,000 } \\
\text { inhabitans) }\end{array}$ & 19 & $10.56 \%$ & 15 & $9.62 \%$ & \\
\hline & City (>50,000 inhabitans) & 124 & $68.89 \%$ & 116 & $74.36 \%$ & \\
\hline \multirow{3}{*}{$\begin{array}{c}\text { Working } \\
\text { status * }\end{array}$} & Unemployed & 10 & $5.56 \%$ & 18 & $11.54 \%$ & \multirow{3}{*}{$<0.001$} \\
\hline & Employed & 59 & $32.78 \%$ & 76 & $48.72 \%$ & \\
\hline & Retired & 111 & $61.67 \%$ & 62 & $39.74 \%$ & \\
\hline \multirow{2}{*}{ Marriage * } & Living alone & 77 & $42.78 \%$ & 49 & $31.41 \%$ & \multirow{2}{*}{0.032} \\
\hline & Living with partner & 103 & $57.22 \%$ & 107 & $68.59 \%$ & \\
\hline \multirow{3}{*}{$\begin{array}{c}\text { Financial } \\
\text { status * }\end{array}$} & Below average & 63 & $35.00 \%$ & 32 & $20.51 \%$ & \multirow{3}{*}{0.002} \\
\hline & Average & 115 & $63.89 \%$ & 116 & $74.36 \%$ & \\
\hline & Above average & 2 & $1.11 \%$ & 8 & $5.13 \%$ & \\
\hline \multirow{4}{*}{ Salary * } & $<3000$ kn & 101 & $56.11 \%$ & 49 & $31.41 \%$ & \multirow{4}{*}{$<0.001$} \\
\hline & $3000-6000$ kn & 68 & $37.78 \%$ & 80 & $51.28 \%$ & \\
\hline & $6000-10,000 \mathrm{kn}$ & 11 & $6.11 \%$ & 22 & $14.10 \%$ & \\
\hline & $>10,000 \mathrm{kn}$ & 0 & $0.00 \%$ & 5 & $3.21 \%$ & \\
\hline
\end{tabular}

* Fisher-Freeman-Halton's test, values in bold are statistically significant. 
Table 2. Age differences between the two groups of participants according to the outcome of chronic pain treatment: Mann-Whitney U test.

\begin{tabular}{|c|c|c|c|c|c|c|c|c|}
\hline \multirow{2}{*}{\multicolumn{2}{|c|}{ Groups }} & \multirow[b]{2}{*}{$\mathbf{N}$} & \multirow[b]{2}{*}{ Minimum } & \multirow[b]{2}{*}{ Maximum } & \multicolumn{3}{|c|}{ Percentiles } & \multirow[b]{2}{*}{$p$} \\
\hline & & & & & 25th & $\begin{array}{c}\text { 50th } \\
\text { (Median) }\end{array}$ & 75th & \\
\hline \multirow{2}{*}{ Age (years) } & NRS 4-10 & 180 & 28.00 & 88.00 & 54.00 & 62.50 & 71.75 & \multirow{2}{*}{$<0.001$} \\
\hline & NRS 0-3 & 156 & 20.00 & 83.00 & 46.25 & 57.00 & 66.00 & \\
\hline
\end{tabular}

Differences in comorbidities between participants with successful chronic non-malignant pain management (NRS 0-3) and participants where the intensity of pain was not reduced despite treatment (NRS 4-10) are shown in Table 3. Participants where the intensity of pain was not reduced despite treatment (NRS 4-10) had a significantly higher prevalence of arthritis $(p<0.001)$, osteoporosis $(p=0.017)$, peripheral vascular disease $(p=0.029)$, diseases of the upper digestive system $(p=0.002)$, depression $(p=0.010)$, anxiety or panic disorder $(p=0.008)$, hearing and degenerative disorders $(p=0.022$ and $p<0.001)$.

Table 3. Functional Comorbidity Index (FCI).

\begin{tabular}{|c|c|c|c|c|c|c|c|c|}
\hline \multirow[b]{2}{*}{ Groups } & & \multirow[b]{2}{*}{$\mathbf{N}$} & \multirow[b]{2}{*}{ Minimum } & \multirow[b]{2}{*}{ Maximum } & \multicolumn{3}{|c|}{ Percentiles } & \multirow[b]{2}{*}{$p$} \\
\hline & & & & & 25th & $\begin{array}{c}\text { 50th } \\
\text { (Median) }\end{array}$ & 75th & \\
\hline \multirow{2}{*}{$\begin{array}{c}\text { The Functional } \\
\text { Comorbidity Index (FCI) }\end{array}$} & NRS 0-3 & 156 & 0.00 & 9.00 & 1.00 & 2.00 & 3.00 & \multirow{2}{*}{$<0.001$} \\
\hline & NRS 4-10 & 180 & 0.00 & 10.00 & 2.00 & 3.00 & 5.00 & \\
\hline
\end{tabular}

Values in bold are statistically significant.

Table 3 Differences in comorbidities between the two groups of participants according to the outcome of chronic pain treatment.

Differences in general anxiety and depression scores between participants with successful chronic non-malignant pain management (NRS 0-3) and participants where the intensity of pain was not reduced despite treatment (NRS 4-10) are shown in Table 4.

Table 4. Differences in general anxiety and depression between the two groups of participants according to the outcome of chronic pain treatment: Mann-Whitney U test.

\begin{tabular}{|c|c|c|c|c|c|c|c|c|}
\hline & & \multirow[b]{2}{*}{$\mathbf{N}$} & \multirow[b]{2}{*}{ Minimum } & \multirow[b]{2}{*}{ Maximum } & \multicolumn{3}{|c|}{ Percentiles } & \multirow[b]{2}{*}{$p$} \\
\hline & & & & & 25 th & $\begin{array}{c}\text { 50th } \\
\text { (Median) }\end{array}$ & 75 th & \\
\hline \multirow{2}{*}{$\begin{array}{c}\text { GAD-7 } \\
\text { score }\end{array}$} & NRS 4-10 & 180 & 0.00 & 21.00 & 4.00 & 7.00 & 12.00 & \multirow{2}{*}{$<0.001$} \\
\hline & NRS 0-3 & 156 & 0.00 & 21.00 & 1.00 & 3.00 & 6.75 & \\
\hline \multirow{2}{*}{$\begin{array}{l}\text { CES-D } \\
\text { score }\end{array}$} & NRS 4-10 & 180 & 3.00 & 51.00 & 18.00 & 25.00 & 33.75 & \multirow{2}{*}{$<0.001$} \\
\hline & NRS 0-3 & 156 & 3.00 & 47.00 & 8.00 & 14.00 & 21.75 & \\
\hline
\end{tabular}

Values in bold are statistically significant.

In participants where the intensity of pain was not reduced despite treatment (NRS $4-10)$, there were higher level of anxiety $(p<0.001)$ and higher CES-D score $(p<0.001)$.

Differences in religiosity (The Duke University Religion Index-DUREL) and SFSS scores between participants with successful chronic non-malignant pain management (NRS 0-3) and participants where the intensity of pain was not reduced despite treatment (NRS 4-10) are shown in Table 5 (SFSS). There was no significant difference in the Durel score, but in participants where the intensity of pain was not reduced despite treatment (NRS $4-10)$, there was a significantly lower SFSS score $(p=0.035)$. 
Table 5. Differences in religiosity (The Duke University Religion Index-DUREL) and social factors social support (SFSS) scores between the two groups of participants according to the outcome of chronic pain treatment: Mann-Whitney U test.

\begin{tabular}{|c|c|c|c|c|c|c|c|c|}
\hline & & \multirow[b]{2}{*}{$\mathbf{N}$} & \multirow[b]{2}{*}{ Minimum } & \multirow[b]{2}{*}{ Maximum } & \multicolumn{3}{|c|}{ Percentiles } & \multirow[b]{2}{*}{$p$} \\
\hline & & & & & 25th & $\begin{array}{c}\text { 50th } \\
\text { (Median) }\end{array}$ & 75th & \\
\hline \multirow{2}{*}{ DUREL score } & NRS 4-10 & 180 & 5.00 & 27.00 & 13.00 & 17.00 & 21.75 & \multirow{2}{*}{0.583} \\
\hline & NRS 0-3 & 156 & 5.00 & 26.00 & 13.00 & 17.00 & 21.00 & \\
\hline \multirow{2}{*}{ SFSS } & NRS 4-10 & 180 & 9.00 & 28.00 & 18.00 & 22.00 & 26.00 & \multirow{2}{*}{0.035} \\
\hline & NRS 0-3 & 156 & 13.00 & 28.00 & 20.25 & 23.00 & 25.00 & \\
\hline
\end{tabular}

Values in bold are statistically significant.

Differences in quality of life (The World Health Organization Quality of Life-Brief Version questionnaire, WHOQOL-BREF) between both groups are shown in Table 6. All of the quality-of-life domains were significantly poorer among participants where the intensity of pain was not reduced despite treatment (NRS 4-10) on the $p<0.001$ level and in most cases (except social domain) with a median value below recommended quality of life values of 60 .

Table 6. Differences in quality of life between the two groups of participants according to the outcome of chronic pain treatment: Mann-Whitney U test.

\begin{tabular}{|c|c|c|c|c|c|c|c|c|}
\hline & & \multirow[b]{2}{*}{$\mathbf{N}$} & \multirow[b]{2}{*}{ Minimum } & \multirow[b]{2}{*}{ Maximum } & \multicolumn{3}{|c|}{ Percentiles } & \multirow[b]{2}{*}{$p$} \\
\hline & & & & & 25th & $\begin{array}{c}\text { 50th } \\
\text { (Median) }\end{array}$ & 75th & \\
\hline \multirow{2}{*}{$\begin{array}{l}\text { WHOQOL-BREF } \\
\text { PHYS }\end{array}$} & NRS 4-10 & 180 & 3.57 & 71.43 & 32.14 & 39.29 & 50.00 & \multirow{2}{*}{$<0.001$} \\
\hline & NRS 0-3 & 156 & 25.00 & 92.86 & 43.75 & 57.14 & 67.86 & \\
\hline \multirow{2}{*}{$\begin{array}{c}\text { WHOQOL-BREF } \\
\text { PSYCH }\end{array}$} & NRS 4-10 & 180 & 16.67 & 100.00 & 45.83 & 54.17 & 70.83 & \multirow[b]{2}{*}{$<0.001$} \\
\hline & NRS 0-3 & 156 & 33.33 & 95.83 & 58.33 & 70.83 & 79.17 & \\
\hline \multirow{2}{*}{$\begin{array}{l}\text { WHOQOL-BREF } \\
\text { SOCIAL }\end{array}$} & NRS 4-10 & 180 & 8.33 & 100.00 & 50.00 & 66.67 & 75.00 & \multirow{2}{*}{$<0.001$} \\
\hline & NRS 0-3 & 156 & 25.00 & 100.00 & 58.33 & 75.00 & 83.33 & \\
\hline \multirow{2}{*}{$\begin{array}{c}\text { WHOQOL-BREF } \\
\text { ENVIR }\end{array}$} & NRS 4-10 & 180 & 15.63 & 93.75 & 46.88 & 56.25 & 65.63 & \multirow{2}{*}{$<0.001$} \\
\hline & NRS 0-3 & 156 & 31.25 & 90.63 & 56.25 & 65.63 & 74.22 & \\
\hline
\end{tabular}

Values in bold are statistically significant.

Table 7 shows the differences in patient satisfaction between participants with successful chronic non-malignant pain management (NRS 0-3) and participants where the intensity of pain was not reduced despite treatment (NRS 4-10).

Participants with successful chronic non-malignant pain management (NRS 0-3) had significantly higher scores in PSQ18 Technical Quality $(p=0.005)$, PSQ18 Interpersonal Manner $(p=0.006)$ and PSQ18 Accessibility and Convenience $(p=0.047)$.

Differences in the self-treatment of pain practice between 2 groups of participants revealed a significantly higher proportion of positive answers on the claim "Self-treatment of pain was stimulated by a pharmacist" among NRS 4-10 group (22.8\%) compared to NRS 0-3 group (12.2\%) ( $p=0.011)$. Moreover, there was a significantly higher proportion of positive answers on the claim that inaccessibility of doctors and therapies affects the decision to self-treatment of pain, with 31.8\% positive answers in NRS 4-10 group and $21.2 \%$ positive answers in NRS $0-3$ group $(p=0.028)$. 
Table 7. Differences in patient satisfaction (PSQ18) between the two groups of participants according to the outcome of chronic pain treatment.

\begin{tabular}{|c|c|c|c|c|c|c|c|c|}
\hline & & \multirow[b]{2}{*}{$\mathbf{N}$} & \multirow[b]{2}{*}{ Minimum } & \multirow[b]{2}{*}{ Maximum } & \multicolumn{3}{|c|}{ Percentiles } & \multirow[b]{2}{*}{$p$} \\
\hline & & & & & 25th & $\begin{array}{c}\text { 50th } \\
\text { (Median) }\end{array}$ & 75th & \\
\hline \multirow{2}{*}{$\begin{array}{l}\text { PSQ18 General } \\
\text { Satisfaction }\end{array}$} & NRS 4-10 & 180 & 1.00 & 5.00 & 2.00 & 3.00 & 3.50 & \multirow{2}{*}{0.539} \\
\hline & NRS 0-3 & 156 & 1.00 & 5.00 & 2.50 & 3.00 & 3.50 & \\
\hline \multirow{2}{*}{$\begin{array}{c}\text { PSQ18 Technical } \\
\text { Quality }\end{array}$} & NRS 4-10 & 180 & 1.50 & 5.00 & 2.75 & 3.25 & 3.75 & \multirow{2}{*}{0.005} \\
\hline & NRS 0-3 & 156 & 1.50 & 4.50 & 3.00 & 3.50 & 3.75 & \\
\hline \multirow{2}{*}{$\begin{array}{c}\text { PSQ18 Interpersonal } \\
\text { Manner }\end{array}$} & NRS 4-10 & 180 & 1.00 & 5.00 & 3.00 & 3.50 & 4.00 & \multirow{2}{*}{0.006} \\
\hline & NRS 0-3 & 156 & 2.00 & 5.00 & 3.50 & 4.00 & 4.38 & \\
\hline \multirow{2}{*}{$\begin{array}{c}\text { PSQ18 } \\
\text { Communication }\end{array}$} & NRS 4-10 & 180 & 1.00 & 5.00 & 2.50 & 3.50 & 4.00 & \multirow[b]{2}{*}{0.099} \\
\hline & NRS 0-3 & 156 & 1.50 & 4.50 & 3.00 & 3.50 & 4.00 & \\
\hline \multirow{2}{*}{$\begin{array}{c}\text { PSQ18 Financial } \\
\text { Aspects }\end{array}$} & NRS 4-10 & 180 & 1.00 & 5.00 & 2.00 & 3.00 & 4.00 & \multirow{2}{*}{0.269} \\
\hline & NRS 0-3 & 156 & 1.00 & 5.00 & 2.50 & 3.00 & 4.00 & \\
\hline \multirow{2}{*}{$\begin{array}{l}\text { PSQ18 Time Spent } \\
\text { with Doctor }\end{array}$} & NRS 4-10 & 180 & 1.00 & 5.00 & 2.50 & 3.00 & 4.00 & \multirow[b]{2}{*}{0.447} \\
\hline & NRS 0-3 & 156 & 1.00 & 5.00 & 2.50 & 3.00 & 4.00 & \\
\hline \multirow{2}{*}{$\begin{array}{l}\text { PSQ18 Accessibility } \\
\text { and Convenience }\end{array}$} & NRS 4-10 & 180 & 1.00 & 5.00 & 2.00 & 2.50 & 3.25 & \multirow{2}{*}{0.047} \\
\hline & NRS 0-3 & 156 & 1.00 & 5.00 & 2.25 & 2.75 & 3.50 & \\
\hline
\end{tabular}

Values in bold are statistically significant.

\subsection{Inferential Statistics—Logistic Regression Analysis}

Prediction of poor outcome of the treatment of patients with chronic non-malignant pain with the dimensions of pain (intensity, quality, localization), psychological factors (depression, anxiety), social factors (social support) and self-treatment is shown in Table 1. Binary logistic regression model is statistically significant $(p<0.001)$ and explains $64.5 \%$ of dependent variable variance. The model was statistically significant $(p<0.001)$, with $\mathrm{r} 2$ (Nagelkerke R Square) $64.5 \%$ and with $82.4 \%$ of correct classification of participants.

\section{Discussion}

The poor outcome of the treatment of chronic non-malignant pain in a multivariate binary logistic regression model is statistically significantly associated with the lower quality of life and higher depression level. The outcome of the treatment was not directly related to social support, but solitary life (without partner) was. The typical patient with the poor pain management outcome was retired, presented a depressive mood, and had pain that disturbed general activity and sleeping. Following bivariate analysis, several predictors showed a significant prediction of belonging to a group with unsuccessful treatment outcome (Table 8).

Among socio-demographic characteristics, the most significant predictor was retired compared to unemployed, followed by living alone. Although women prevailed in both study groups, gender still did not appear to be a predictor of unsuccessful outcome. It is assumed that women more frequently report their pain and differently react to pain, as described by Wijnhoven HA et al. [37]. Regarding the age of subjects, those in the group with unsuccessful outcome were somewhat older compared to those with successful pain treatment outcome, but age still did not appear to be a significant predictor. The age in this study can speak in favor of results indicating that retired subjects were predictors of unsuccessful treatment outcome.

In the study of Breivik et al., elderly persons who suffered from chronic pain were more represented in most of the countries studied, for example, in Germany, the Nordic countries, the Netherlands, France and Spain, while in Israel, Poland and Italy younger age groups suffered more from chronic non-malignant pain [1]. In a large study carried out in 43 countries, Stubbs et al. demonstrated significant association of chronic pain with older 
age, female gender, lower educational level, and urban environment [38]. Azevedo et al. also found out the same [39]. Several studies demonstrated similar risk factors associated with chronic pain, such as low level of education, low family income, manual work, and being single (those living without partners) [40-42].

Table 8. Prediction of poor outcome of the treatment of patients with chronic non-malignant pain with the dimensions of pain (intensity, quality, localization), psychological factors (depression, anxiety), social factors (social support) and self-treatment: binary logistic regression.

\begin{tabular}{|c|c|c|c|c|}
\hline & \multirow{2}{*}{ OR } & \multicolumn{2}{|c|}{$95 \% \mathrm{CI}$} & \multirow{2}{*}{$p$} \\
\hline & & Lower & Upper & \\
\hline Age (years) & 0.99 & 0.96 & 1.03 & 0.753 \\
\hline Working status: unemployed & & & & 0.089 \\
\hline Working status: employed & 1.58 & 0.48 & 5.29 & 0.454 \\
\hline Working status: retired & 3.73 & 1.07 & 12.97 & 0.039 \\
\hline Education & 0.83 & 0.56 & 1.24 & 0.375 \\
\hline Living alone & 2.16 & 1.03 & 4.53 & 0.043 \\
\hline Financial status: below average & & & & 0.568 \\
\hline Financial status: average & 0.73 & 0.32 & 1.67 & 0.455 \\
\hline Financial status: above average & 0.25 & 0.01 & 4.82 & 0.357 \\
\hline GAD-7 score & 0.91 & 0.83 & 1.00 & 0.057 \\
\hline CES-D score & 1.08 & 1.02 & 1.14 & 0.009 \\
\hline SFSS & 1.04 & 0.95 & 1.15 & 0.395 \\
\hline WHOQOL-BREF PHYS & 0.95 & 0.91 & 0.99 & 0.009 \\
\hline WHOQOOL-BREF PSYCH & 1.03 & 1.00 & 1.07 & 0.067 \\
\hline WHOQOL-BREF ENVIR & 1.00 & 0.97 & 1.04 & 0.845 \\
\hline Self-treatment of pain was stimulated by a pharmacist & 0.80 & 0.34 & 1.89 & 0.614 \\
\hline $\begin{array}{c}\text { Self-treatment: inaccessibility of doctors } \\
\text { and therapies }\end{array}$ & 2.89 & 1.30 & 6.44 & 0.009 \\
\hline PSQ18 Technical Quality & 1.33 & 0.64 & 2.77 & 0.440 \\
\hline PSQ18 Interpersonal Manner & 0.67 & 0.40 & 1.13 & 0.132 \\
\hline PSQ18 Accessibility and Convenience & 1.29 & 0.76 & 2.19 & 0.345 \\
\hline
\end{tabular}

Values in bold are statistically significant.

Studies demonstrated that social support is associated with better general health conditions and a higher subjective sense of well-being because it provides people with a feeling of belonging and support [43] and it is directly related to satisfaction with life [44]. It is more likely that people with closer relationships will: be more included in social activities; have better appetite; have healthier behavior and pay more attention to their health [45]. In our study, we found out the association of higher social support and favorable outcome of treatment of pain in bivariate statistics, but social support was not a significant predictor in the multivariate model.

Holtzman et al., in their study, show that social support has an effect on chronic pain intensity, and various sources of support can encourage the person to use the facing strategy [20]. Other studies also suggest that the combination of emotional support of family or other important persons, in combination with informational physician's support, can help in the process of acceptance in persons with chronic pain [46]. Encouraged and emotionally supported patients have a higher probability of participation in every day, social, professional, and extracurricular activities [47-51]. Still, the social support changes over time and becomes limited [52] due to the chronic nature of pain, which is persistent, long-lasting, and often silent [53,54].

Among psychological factors, the significant predictor in the model of our study was the higher CES-D Score. These results are supported by other studies which indicated that depression and anxiety, as the most common disorders in a general population $[55,56]$ are frequently present in patients with chronic pain as well [2]. According to some authors, depression becomes a key factor and predictor of painful symptoms such as musculoskeletal pain $[57,58]$. Beyer believes that psychosocial factors have higher impact on pain chroni- 
fication than somatic problems and that depression and anxiety are the main triggers in pain chronification [59]. Other studies also revealed the association of higher intensity pain with depression [7] and that concomitantly present depression complicates the treatment of pain and reduces the success of treatment [7-10], which is in line with our results.

In our model level of anxiety was not a predictor of the treatment outcome, but we found an association between anxiety and worse outcomes in bivariate statistics.

Lower WHOQOL-BREF PHYS) also showed the association with unsuccessful treatment. Since this study was cross-sectional it was difficult to determine whether the lower WHOQOL-BREF PHYS was the cause or the consequence of unsuccessful treatment outcome, which is at the same time one of the disadvantages of cross-sectional studies. However, the bivariate analysis revealed that all of the WHOQOL-BREF domains were significantly lower in the group with the unsuccessful outcome of pain treatment, while in the model, logistic regression showed that only the physical domain was a predictor of an unsuccessful outcome. Other studies also support the conclusion that chronic pain is associated with a negative impact on the quality of life, both physical and mental [60] and results in its aggravation [61]. The chronic pain is a complex experience. Except that it is disturbing for an individual because of its long-lasting nature, it has also psychological, social, and economic consequences. It causes problems with walking, house chores and engaging in even simple activities such as sitting or standing [1,62,63]. In addition, chronic pain impacts social interaction as well, because it constrains patient's activities and social contacts. Such an interpenetration of all aspects of life caused by chronic pain eventually results in the patient's lower quality of life [64].

In addition to other factors, the outcome of chronic pain treatment can be influenced by the factor of patient satisfaction with the support of healthcare providers and with function of healthcare services. Among seven domains assessed, we gathered statistically significant differences between two study groups in three domains. The results obtained indicated that participants with successful chronic non-malignant pain management had significantly higher scores in PSQ18 Technical Quality, Interpersonal Manner and Accessibility and Convenience. It can be concluded that the patient's satisfaction with health services was of great importance, where it is important to identify weaknesses in the healthcare system by "patient's eyes", as it allows weaknesses identified by patients to accomplish results in its improvement [65]. Positive or negative patient's assessments of certain dimensions are of vital importance for monitoring the quality of care in medical institutions [66]. The patient satisfaction, as a predictor of a more favorable treatment outcome, may be the result of better acceptance of medical advice and treatment, use of services and improvement of relations between the physician and patient [67].

Significant predictor of an unsuccessful outcome of chronic, non-malignant pain treatment was the self-treatment from the inaccessibility of doctors and therapies. Similar results were gathered in the first, qualitative part of the study, where the inaccessibility of doctors and long waiting time for the treatment were the most significant factors associated with the decision on self-treatment, which has been confirmed by other studies as well $[68,69]$. According to Loese and Melzac, in spite of various treatment options, chronic pain will probably persist even after the end of treatment and will be understood as a condition that has not been cured [70]. This indicates that, in many cases, patients have to treat their pain themselves and on a daily basis [71] and, according to Barlow, take actions to identify, treat and manage, and adopt behaviors that influence their health [72]. The biopsychosocial model of chronic pain treatment implies the program of multidisciplinary approach which guides the patient to adopt his/her diagnosis and learn how to live with chronic pain $[73,74]$. According to this model, psychological and behavioral factors (self-assessment of quality of life) and social factors (educational level, medical care availability), in addition to biological ones, have also a high impact on disease outcome i.e., disease resolution [75]. 


\section{Conclusions}

It can be said that the typical patient with an unsuccessful outcome of pain management in our study was retired, living alone, with depressive behavior and with pain that disturbed general activity (physical aspect of QoL) and sleeping. Since the outcome of chronic, non-malignant pain treatment is, in addition to medical factors, influenced by many other, biopsychosocial factors, the approach to treatment should be adjusted to those diversities. Based on the results of our study, it can be concluded that the principle of treatment of patients with chronic, non-malignant pain should take into account a biopsychosocial approach with individually adjusted procedures.

\section{Limitations of the Study}

Since this study was cross-sectional, it is not possible to determine whether some factors were the cause or the consequence of unsuccessful treatment outcome, which is at the same time one of the disadvantages of cross-sectional studies. For instance, logistic regression has shown that retirement status is a strong predictor of the outcome when treating chronic, non-malignant pain. However, it is debatable whether the patients in retirement experience stronger pain or if the chronic pain has driven patients into early retirement.

The weaknesses of this study are not only methodological but also statistical. For testing differences in quantitative variables, we were forced to use the Mann-Whitney $\mathrm{U}$ (MWU) test because the Kolmogorov-Smirnov (KS) test has shown the non-normal distribution in measured variables. The MWU test is generally less powerful than its parametric counterpart [76], so there is an increased probability of false-negative results in some variables. For non-normal quantitative data, a transformation could be used to obtain a more Gaussian distribution, however, since the interpretation of transformed data is usually less intuitive, such procedures were not used.

Author Contributions: Conceptualization, D.P., I.K., V.M.K.; methodology, D.P.; formal analysis, D.P. and M.M.; investigation, I.K.; writing-original draft preparation, I.K.; supervision, D.P. Data analysis and interpretation were undertaken by M.M., A.F., B.I., V.K., Š.O.V., J.P.; P.K. contributed to data processing and cleaning. All authors have read and agreed to the published version of the manuscript.

Funding: This research received no external funding.

Institutional Review Board Statement: The study was approved by the Ethics Committee of the University Hospital Center (UHC) "Sestre milosrdnice" in Zagreb, Croatia, at its regular session held on 25 May 2016, file \# EP-7811/16-6. The Ethical Committee of the University Hospital Center (UHC) "Sestre milosrdnice" operates in line with the principles of the International Conference on Harmonisation (ICH GCP) and the Helsinki Declaration.

Informed Consent Statement: Informed consent was obtained from all the subjects involved in the study.

Data Availability Statement: The datasets generated and analyzed for this study can be requested from the correspondent author. The data are not publicly available due to policy of institutions which gave ethical approval to the study.

Acknowledgments: We would like to acknowledge the assistance and support of Jelka Petrak in the preparation and proofreading of this paper. Many thanks to the whole team at the Pain Clinic from UHC "Sestre milosrdnice" as well as to all the patients who agreed to take part in the study and to complete questionnaires.

Conflicts of Interest: The authors declare no conflict of interest. 


\section{References}

1. Breivik, H.; Collett, B.; Ventafridda, V.; Cohen, R.; Gallacher, D. Survey of chronic pain in Europe: Prevalence, impact on daily life, and treatment. Eur. J. Pain 2006, 10, 287-333. [CrossRef] [PubMed]

2. Croft, P.; Blyth, F.M.; van der Windt, D. The Global Occurrence of Chronic Pain: An Introduction. In Chronic Pain Epidemiology. From Aetiology to Public Health; Oxford University Press: New York, NY, USA, 2010; pp. 9-18.

3. Adler, R.H. The term "chronic" with respect to pain should be dropped. Clin. J. Pain 2000, 16, 365. [CrossRef] [PubMed]

4. American Psychiatric Association (APA). Diagnostic and Statistical Manual of Mental Disorders (DSM-IV), 4th ed.; American Psychiatric Association: Washington, DC, USA, 1994.

5. Vellucci, R. Heterogeneity of chronic pain. Clin. Drug Investig. 2012, 32, 3-10. [CrossRef] [PubMed]

6. Jones, J.; Rutledge, D.N.; Jones, K.D.; Matallana, L.; Rooks, D.S. Self-assessed physical function levels of women with fibromyalgia: A national survey. Womens Health Issues 2008, 18, 406-412. [CrossRef]

7. Seed, H.; Zakaria, H.; Perumal, M.; Baharudin, A. Depression among chronic pain patients at Hospital Tengku Ampuan Rahimah, Klang. Med. J. Malaysia 2015, 70, 303-306.

8. Knaster, P.; Estlander, A.M.; Karlsson, H.; Kaprio, J.; Kalso, E. Diagnosing Depression in Chronic Pain Patients: DSM-IV Major Depressive Disorder vs. Beck Depression Inventory (BDI). PLoS ONE 2016, 11, e0151982. [CrossRef]

9. Padovani, M.T.; Martins, M.R.I.; Venâncio, A.; Forni, J.E.N. Anxiety, depression, and quality of life in individuals with phantom limb pain. Acta Ortop. Bras. 2015, 23, 107-110. [CrossRef]

10. Zebenholzer, K.; Broessner, G.; Lampl, C.; Luthringshausen, G.; Lechne, A.; Wuschitz, A.; Obmann, S.-M.; Berek, K.; Wöber, C. Impact of depression and anxiety on burden and management of episodic and chronic headaches-A cross-sectional multicentre study in eight Austrian headache centres. J. Headache Pain 2016, 17, 15. [CrossRef]

11. Jafarinia, M.; Afarideh, M.; Tafakhori, A.; Arbabi, M.; Ghajar, A.; Noorbala, A.A.; Saravi, M.A.; Agah, E.; Akondzadeh, S. Efficacy and safety of oral ketamine versus diclofenac to alleviate mild to moderate depression in chronic pain patients: A double-blind, randomized, controlled trial. J. Affect. Disord. 2016, 204, 1-8. [CrossRef]

12. Currie, S.R.; Wang, J.L. Chronic back pain and major depression in the general Canadian population. Pain 2004, 107, 54-60. [CrossRef]

13. Druss, B.G.; Rosenheck, R.A.; Sledge, W.H. Health and disability costs of depressive illness in a major US corporation. Am. J. Psychiatry 2000, 157, 1274-1278. [CrossRef]

14. Smith, B.; Macfarlane, G.; Torrance, N. Epidemiology of chronic pain, from the laboratory to the bus stop: Time to add understanding of biological mechanisms to the study of risk factors in population-based research. Pain 2007, 127, 5-10. [CrossRef]

15. Stenholm, S.; Rantanen, T.; Heliovaara, M.; Koskinen, S. The mediating role of C-reactive protein and handgrip strength between obesity and walking limitation. J. Am. Geriatr. Soc. 2008, 56, 462-469. [CrossRef]

16. Shaw, W.S.; Campbell, P.; Nelson, C.C.; Main, C.J.; Linton, S.J. Effects of workplace, family, and cultural influences on low back pain: What opportunities exist to address social factors in general consultations? Best Pract. Res. Clin. Rheumatol. 2013, 27, 637-648. [CrossRef]

17. Hestbaek, L.; Korsholm, L.; Leboeuf-yde, C.; Kyvik, K.O. Does socioeconomic status in adolescents predict low back pain in adulthood? A repeated cross-sectional study of 4771 Danish adolescents. Eur. Spine J. 2008, 17, 1727-1734. [CrossRef]

18. Meucci, R.D.; Fassa, A.G.; Paniz, V.M.; Silva, M.C.; Wegman, D.H. Increase of chronic low back pain prevalence in a medium-sized city of southern Brazil. BMC Musculoskelet. Disord. 2013, 1, 155. [CrossRef]

19. Blackburn, A. Living with Pain or Living in Pain: Narrative Journeys with Low Back Pain. Ph.D. Thesis, Northumbria University, Newcastle, UK, 2011. Available online: http:/ / nrl.northumbria.ac.uk/1536/ (accessed on 10 February 2021).

20. Holtzman, S.; Newth, S.; Delongis, A. The role of social support in coping with daily pain among patients with rheumatoid arthritis. J. Health Psychol. 2004, 9, 677-695. [CrossRef]

21. Institute for Health Metric and Evaluation. Available online: http:/ / www.healthdata.org/croatia (accessed on 10 September 2019).

22. Kovačević, I.; Kogler, V.M.; Turković, T.M.; Dunkić, L.F.; Ivanec, Ž.; Petek, D. Self-care of chronic musculoskeletal painExperiences and attitudes of patients and health care providers. BMC Musculoskelet. Disord. 2018, 19, 76. [CrossRef]

23. Short-form Patient Satisfaction Questionnaire (PSQ-18). Available online: http://www.rand.org/content/dam/rand/www / external/health/surveys_tools/psq/psq18_survey.pdf (accessed on 10 February 2021).

24. Ware, J.E., Jr.; Snyder, M.K.; Wright, W.R.; Davies, A.R. Defining and measuring patient satisfaction with medical care. Eval. Program. Plan. 1983, 6, 247-263. [CrossRef] [PubMed]

25. Groll, D.L.; To, T.; Bombardier, C.; Wright, J.G. The development of a comorbidity index with physical function as the out-come. J. Clin. Epidemiol. 2005, 58, 595-602. [CrossRef]

26. Eaton, W.; Smith, C.; Ybarra, M.; Muntaner, C.; Tien, A. Center for Epidemiologic Studies Depression Scale: Review and Revision (CESD and CESD-R). In The Use of Psychological Testing for Treatment Planning and Outcomes Assessment: Instruments for Adults, 3rd ed.; Spitzer, R.L., Maurish, M.E., Eds.; Routledge: New York, NY, USA, 2004; pp. 363-377.

27. Kroenke, K.; Williams, J.B.; Löwe, B. Anxiety disorders in primary care: Prevalence, impairment, comorbidity, and detection. Arch. Intern. Med. 2006, 166, 1092-1097. [CrossRef]

28. Madžar, T.; Milošević, M.; Hrabač, P.; Heningsberg, N. Psychological aspects of sports injuries among male professional soccer players in Croatia. Kinesiology 2017, 49, 84-91. [CrossRef] 
29. Koenig, H.G.; Büssing, A. The Duke University Religion Index (DUREL): A Five-Item Measure for Use in Epidemological Studies. Religions 2010, 1, 78-85. [CrossRef]

30. Mihaljević, S. The Effect of Spirituality on Suicidality and Rate of Recovery of Subjects with Depression. Ph.D. Thesis, University of Zagreb, Zagreb, Croatia, 2014.

31. Šverko, B.; Galić, Z.; Seršić, D.M.; Galešić, M. Unemployed people in search of a job: Reconsidering the role of search behavior. J. Vocat. Behav. 2008, 72, 415-428. [CrossRef]

32. The WHOQOL Group. Development of the World Health Organization WHOQOL-BREF quality of life assessment. Psychol. Med. 1998, 28, 551-558. [CrossRef]

33. World Health Organization. Programme on Mental Health. WHOQOL-BREF Introduction, Administration, Scoring and Generic Version of the Assessment. Field Trial Version. 1996. Available online: https://www.who.int/mental_health/media/en/76.pdf (accessed on 20 February 2021).

34. The Whoqol Group. The World Health Organization Quality of Life Assessment (WHOQOL): Development and general psychometric properties. Soc. Sci. Med. 1998, 46, 1569-1585. [CrossRef]

35. Pibernik-Okanovic, M. Psychometric properties of the World Health Organisation quality of life questionnaire (WHOQOL-100) in diabetic patients in Croatia. Diabetes Res. Clin. Pract. 2001, 51, 133-143. [CrossRef]

36. Abbey, A.; Abramis, D.J.; Caplan, R.D. Effects of different sources of social support and social conflict on emotional wellbeing. Basic Appl. Soc. Psychol. 1985, 6, 11-29. [CrossRef]

37. Wijnhoven, H.A.; de Vet, H.C.; Picavet, H.S. Explaining sex differences in chronic musculoskeletal pain in a general population. Pain 2006, 124, 158-166. [CrossRef]

38. Stubbs, B.; Koyanagi, A.; Thompson, T.; Veronese, N.; Carvalho, A.F.; Solomi, M.; Mugisha, J.; Schofield, P.; Cosco, T.; Wilson, N.; et al. The epidemiology of back pain and its relationship with depression, psychosis, anxiety, sleep disturbances, and stress sensitivity: Data from 43 low- and middle-income countries. Gen. Hosp. Psychiatry 2016, 43, 63-70. [CrossRef]

39. Azevedo, L.F.; Costa-Pereira, A.; Mendonca, L.; Dias, C.C.; Castro-Lopes, J.M. Epidemiology of chronic pain: A population-based nationwide study on its prevalence, characteristics, and associated disability in Portugal. J. Pain 2012, 13, 773-783. [CrossRef] [PubMed]

40. Cunningham, L.S.; Kelsey, J.L. Epidemiology of musculoskeletal impairments and associated disabilities. Am. J. Public Health 1984, 74, 574-579. [CrossRef] [PubMed]

41. Bergman, S.; Herrström, P.; Högström, K.; Petersson, I.F.; Svensson, B.; Jacobsson, L.T. Chronic musculoskeletal pain, prevalence rates, and sociodemographic associations in a Swedish population study. J. Rheumatol. 2001, 28, 1369-1377. [PubMed]

42. Urwin, M.; Symmons, D.; Allison, T.; Brammah, T.; Busby, H.; Roxby, M.; Simmons, A.; Williams, G. Estimating the burden of musculoskeletal disorders in the community: The comparative prevalence of symptoms at different anatomical sites, and the relation to social deprivation. Ann. Rheumat. Dis. 1998, 57, 649-655. [CrossRef]

43. Avlund, K.; Damsgaard, M.T.; Holstein, B.E. Social relations and mortality. An eleven-year follow-up study of 70-year old men and women in Denmark. Soc. Sci. Med. 1998, 47, 635-643. [CrossRef]

44. Aquino, J.A.; Russell, D.W.; Cutrona, C.E.; Altmaier, E.M. Employment Status, Social Support, and Life Satisfaction Among the Elderly. Pers. Individ. Differ. 1996, 43, 480-489. [CrossRef]

45. Despot-Lučanin, J. Iskustvo Starenja; Naklada Slap: Jastrebarsko, Croatia, 2003.

46. Kostova, Z.; Caiata-Zufferey, M.; Schulz, P.J. The impact of social support on the acceptance process among RA patients: A qualitative study. Psychol. Health 2014, 29, 1283-1302. [CrossRef]

47. Ressler, P.K.; Bradshaw, Y.S.; Gualtieri, L.; Chui, K.K.H. Communicating the experience of chronic pain and illness through blogging. J. Med. Internet Res. 2012, 14, e143. [CrossRef]

48. Nardon, L.; Aten, K.; Gulanowski, D. Expatriate adjustment in the digital age: The co-creation of online social support resources through blogging. Int. J. Intercult. Rel. 2015, 47, 41-55. [CrossRef]

49. Ziebland, S.; Wyke, S. Health and illness in a connected world: How might sharing experiences on the internet affect people's health? Milbank. Q. 2012, 90, 219-249. [CrossRef]

50. Warwick, R.; Stephen, J.; Christine, C.; Ashworth, P. Social support for women with chronic pelvic pain: What is helpful from whom? Psychol. Health 2004, 19, 117-134. [CrossRef]

51. Merolli, M.M.; Gray, K.; Martin-Sanchez, F.; Lopez-Campos, G. Patient-Reported Outcomes and Therapeutic Affordances of Social Media: Findings From a Global Online Survey of PeopleWith Chronic Pain. J. Med. Internet. Res. 2015, 17, e20. [CrossRef]

52. Fernández-Peña, R.; Molina, J.L.; Valero, O. Personal Network Analysis in the Study of Social Support: The Case of Chronic Pain. Int. J. Environ. Res. 2018, 15, 2695. [CrossRef]

53. Tse, M.M.Y.; Wan, V.T.C.; Ho, S.S.K. Physical exercise: Does it help in relieving pain and increasing mobility among older adults with chronic pain? J. Clin. Nurs. 2011, 20, 635-644. [CrossRef]

54. Kostova, Z.; Caiata-Zufferey, M.; Schulz, P.J. Can social support work virtually? Evaluation of rheumatoid arthritis patients' experiences with an interactive online tool. Pain Res. Manag. 2015, 20, 199-209. [CrossRef]

55. Kessler, R.C.; Ormel, J.; Petukhova, M.; McLaughlin, K.A.; Green, J.G.; Russo, L.; Stein, D.J.; Zaslavsky, A.M.; Aguilar-Gaxiola, S.; Alonso, J.; et al. Development of lifetime comorbidity in the World Health Organization world mental health surveys. Arch. Gen. Psychiatry 2011, 68, 90. [CrossRef] 
56. Wittchen, H.U.; Kessler, R.C.; Beesdo, K.; Krause, P.; Hofler, M.; Hoyer, R. Generalized anxiety and depression in primary care: Prevalence, recognition, and management. J. Clin. Psychiatry 2002, 63, 24-34.

57. Wasserman, R.A.; Brummett, C.M.; Goesling, J.; Tsodikov, A.; Hassett, A.L. Characteristics of chronic pain patients who take opioids and persistently report high pain intensity. Reg. Anesth. Pain Med. 2014, 39, 13-17. [CrossRef]

58. Harrison, A.M.; Silber, E.; Mccracken, L.M.; Moss-Morris, R. Beyond a physical symptom: The importance of psychosocial factors in multiple sclerosis pain. Eur. J. Neurol. 2015, 22, 1443-1452. [CrossRef]

59. Beyer, A.; Steinberger, M. Chronic pain syndrome not caused by cancer an overview. Dtsch. Med. Wochenschr. 2005, 130, 2325-2332. [CrossRef]

60. Langley, P.; Perez Hernandez, C.; Margarit Ferri, C.; Ruiz Hidalgo, D.; Lubian Lopez, M. Pain, health related quality of life and healthcare resource utilization in Spain. J. Med. Econ. 2011, 14, 628-638. [CrossRef]

61. Carmona, L.; Ballina, J.; Gabriel, R.; Laffon, A.; EPISER Study Group. The burden of musculoskeletal diseases in the general population of Spain: Results from a national survey. Ann. Rheum. Dis. 2001, 60, 1040-1045. [CrossRef] [PubMed]

62. Amris, K.; Waehrens, E.E.; Jespersen, A.; Bliddal, H.; Danneskiold-Samsoe, B. Observation-based assessment of functional ability in patients with chronic widespread pain: A crosssectional study. Pain 2011, 152, 2470-2476. [CrossRef] [PubMed]

63. McBeth, J.; Nicholl, B.I.; Cordingley, L.; Davies, K.A.; Macfarlane, G.J. Chronic widespread pain predicts physical inactivity: Results from the prospective EPIFUND study. Eur. J. Pain 2010, 14, 972-979. [CrossRef] [PubMed]

64. Bentsen, S.B.; Hanestad, B.R.; Rustoen, T.; Wahl, A.K. Quality of life in chronic low back pain patients treated with instrumented fusion. J. Clin. Nurs. 2008, 17, 2061-2069. [CrossRef] [PubMed]

65. Marshall, G.N.; Hays, R.D. The Patient Satisfaction Questionnaire Short Form (PSQ-18); RAND Corporation: Santa Monica, CA, USA, 1994.

66. Narimah, A.H.H.; Rizwan, S.O.; Nadhrah, N.R.; Adlina, S.; Hakimi, Z.A.; Nuraliza, A.S. A descriptive cross-sectional study on patient satisfaction in a private hospital in Selangor. Malays. J. Public Health Med. 2006, 6, 6-12. [CrossRef]

67. Ganasegeran, K.; Al-Dubai, S.A.R. Medical professionalism from a socio-cultural perspective: Evaluating medical residents communicative attitudes during the medical encounter in Malaysia. J. Postgrad. Med. 2014, 60, 12-15. [CrossRef] [PubMed]

68. Babić-Banaszak, A.; Kovačić, L.; Mastilica, M.; Babić, S.; Ivanković, D.; Budak, A. The Croatian health survey-Patient's satisfaction with medical service in primary health care in Croatia. Coll. Antropol. 2001, 25, 449-458.

69. Cvitanović, H.; Jančić, E.; Knežević, E.; Kuljanac, I. Satisfaction of patients with healthcare quality in Outpatients dermatology clinic Karlovac. Med. Flumin. 2011, 47, 82-90.

70. Loeser, J.D.; Melzack, R. Pain: An overview. Lancet 1999, 353, 1607-1609. [CrossRef]

71. Bodenheimer, T.; Lorig, K.; Holman, H.; Grumbach, K. Patient self-management of chronic disease in primary care. JAMA 2002, 288, 2469-2475. [CrossRef]

72. Barlow, J.; Wright, C.; Sheasby, J.; Turner, A.; Hainsworth, J. Self-management approaches for people with chronic conditions: A review. Patient. Educ. Couns. 2002, 48, 177-187. [CrossRef]

73. Golden, B.A. A multidisciplinary approach to nonpharmacologic pain management. J. Am. Osteopath. Assoc. 2002, 102, S1-S9.

74. Tan, G.; Alvarez, J.A.; Jensen, M.P. Complementary and alternative medicine approaches to pain management. J. Clin. Psychol. 2006, 62, 1419-1431. [CrossRef]

75. Engel, G.L. The clinical application of the biopsychosocial model. Am. J. Psychiatry 1980, 137, 535-544.

76. Comparative Power of Student T Test and Mann-Whitney U Test for Unequal Sample Sizes and Variances. Available online: https:/ / www.tandfonline.com/doi/abs/10.1080/00220973.1987.10806451 (accessed on 19 September 2019). 